\title{
VALPARAÍSO, POÉTICAS FUNDACIONALES: GONZALO ROJAS, PABLO NERUDA Y PABLO DE ROKHA ${ }^{\mathbf{1}}$ \\ Valparaíso, Foundational Poetics: Gonzalo Rojas, Pablo Neruda and Pablo de Rokha
}

Adolfo de Nordenflycht Bresky*

Resumen

Gonzalo Rojas, Pablo Neruda y Pablo de Rokha, poetas residentes ocasionales de Valparaíso, produjeron textos que manifiestan una disposición fundacional, en el sentido de que poetizan aquello que, desde la mirada de cada poeta, le da fundamento a la ciudadpuerto. El trabajo examina esos textos, advirtiendo en ellos una poética que articula la conciencia acerca del poder instituyente de la palabra con las representaciones del espacio de Valparaíso construidas a partir del diálogo entre el imaginario "geocultural" local y el imaginario poético individual.

Palabras clave: Poéticas fundacionales, Imaginario, Valparaíso, Espacio representado, Constelación poética.

Abstract

Gonzalo Rojas, Pablo Neruda and Pablo De Rokha, occasional residents of Valparaiso, produced texts which demonstrate a foundational disposition, in the sense that they poeticize what, from the perspective of each poet, gives the basement foundation for the city-port. The work examines these texts, warning in them a poetics that articulates the consciousness of the instituting power of the word with the representations of the space of Valparaiso, constructed from the dialogue between the local "geocultural" imaginary and the individual poetic imaginary.

Key words: Foundational poetics, Imaginary, Valparaíso, represented space, Poetic constellation.

\section{INTRODUCCIÓN: DE LA CIUDAD INFUNDADA A LOS TEXTOS FUNDANTES}

En el imaginario colectivo de Valparaíso ha persistido la percepción de que la ciudad nunca fue fundada, si bien entre historiadores y cronistas existe disparidad de ideas. Así, Le Dantec (2003) señala que "[D]es de antiguo ha sido motivo de discusión si hubo fundación de Valparaíso o no la hubo" (18), llegando "decididamente al convencimiento de que hubo fundación" en 1536, basándose en la expresión de Pedro Valdivia al expedir el título de teniente de mar para Juan Bautista Pastene en 1554: "Ahora y de nuevo nombro y señalo que este puerto de Valparaíso", documento que conduce a Le Dantec a determinar que "Valdivia no hacía otra cosa

\footnotetext{
${ }^{1}$ Este artículo ha sido elaborado en el marco del Proyecto Fondecyt $N^{\circ} 1085201$ "Constelaciones del imaginario local en la literatura de Valparaíso (1888-1989): Procedencias y emergencias para una historia efectiva", del cual el autor es investigador responsable.
} 


\section{Adolfo de Nordenflycht}

que reconocer que Valparaíso ya había sido fundado antes [...] por Diego de Almagro en los primeros días de septiembre de 1536" (19). Por su parte, Sáez (2001), revisando estos mismos y otros documentos, y en especial estudiando la expresión adverbial "de nuevo", concluye que "la segunda ciudad de nuestra República no fue fundada ni por Almagro, ni por Valdivia, ni después" (47). ${ }^{2}$ Al margen de la discusión de si el puerto fue nombrado y la ciudad nunca fundada, el hecho es que en 1797 y tras haber quedado olvidada por años en alguna repartición peninsular, se solicita al rey que se otorgue a Valparaíso el título de ciudad, lo que no ocurrió sino en 1802, no obstante la designación sólo llegó en 1811, tomando conocimiento de ella el ya existente Congreso Nacional de Chile el que confirmó el título expedido por real cédula. Estas circunstancias parecen haber fermentado en el imaginario urbano local, en el que ha seguido presente la apreciación de que Valparaíso no fue fundado, fenómeno que no ha dejado de llamar la atención en ciertos poetas que han incorporado la representación del espacio de Valparaíso en algunos de sus textos, asumiendo dialécticamente la relación entre la "mirada" del significado ${ }^{3}$ provista por el imaginario diferencial del poeta y el imaginario colectivo local, "más allá del reconocimiento racional, o no, de los habitantes", 4 en tanto que el poema condensa en sus imágenes "lo que Moles llama la "fuerza problemática", esto es "la capacidad de una entidad imaginaria de incitar, de dirigir la búsqueda" (Durand, 2003:147).

En distintos períodos - y por diversas circunstancias - Neruda, De Rokha y Gonzalo Rojas estuvieron viviendo de paso en Valparaíso, y produjeron diversos textos asociados con su visión de la ciudad-puerto, en un tiempo en que el imaginario social derivaba insensiblemente hacia la nostalgia y lo pintoresco, en medio de una generalizada percepción de declive y decadencia en el sentimiento colectivo de sus habitantes, que parecía reclamar la articulación de un nuevo estadio del imaginario que ofreciera posibilidades identificadoras cuando se perdía aquel imaginario prometeico de la filantropía y

\footnotetext{
${ }^{2}$ Sáez explica que "[T] oda fundación de ciudades durante la Conquista iba acompañada por una serie de actos solemnes que eran inseparables de la ceremonia de fundación. Tales son el nombramiento de autoridades políticas y judiciales, instalación de la horca y del rollo, símbolos de la justicia; planificación de la ciudad, división de ella en solares y asignación de propiedades a los principales caballeros españoles. Nada de eso encontramos en el año 1536 ni después (2001:44).

${ }^{3}$ Tomamos la expresión de Durand, quien señala que el "texto revela en sus 'profundidades' un 'ser pregnante' — utilizo la expresión de Ernst Cassirer- que funda su interés por el lector o el auditor. [...] Pues bien, detrás de los significantes de superficie, pasibles de todos los juegos del semiótico, se oculta la 'mirada' del significado" (2003:154).

${ }^{4}$ Cfr., Adolfo de Nordenflycht. "Quiñónez: poeta, olvidado y porteño (literaturas regionales e imaginarios geoculturales en Chile)", en Estudios Filológicos, № 38 (2003:49-59). En nota al pie, De Nordenflycht puntualiza que "es la poesía la que ilumina creativamente ese imaginario colectivo, incluso para los propios habitantes que conocen la localidad, pero a los que la manifestación poética les señala su identidad (imaginaria) sustantiva, más allá de pintoresquismos y cálculos razonables". Wallace Stevens sostiene: "Las palabras son pensamientos, y no sólo nuestros pensamientos, sino los pensamientos de hombres y mujeres que ignoran lo que ellos mismos están pensando" (1994:32).
} 
el anarquismo, que se correspondía con la ciudad pionera del progreso y la modernización, no solamente a nivel nacional, sino de toda la costa del Pacífico Sur, como lo fuera Valparaíso en el siglo XIX y comienzos del XX.

Entre los textos escritos por estos poetas hemos fijado nuestra atención en aquellos que podrían considerarse como textos fundantes o fundacionales, no en el sentido de ser las primeras manifestaciones de la práctica literaria de Valparaíso, sino en cuanto se trata de textos que toman conciencia del poder "político" de la palabra poética instituyente ${ }^{5}$ que da lugar a la experiencia de una comunidad histórica, que "eleva la naturaleza" y su acontecer en un territorio "al nivel de la historia y del espíritu" (Deleuze, en línea). Se trata entonces de poéticas fundacionales de la ciudad-puerto, en tanto que se incorporan a una eventual historia efectiva — según la concibe Foucault (1988) — de la literatura de Valparaíso, la cual requiere determinar las modalidades de presencia del imaginario "geocultural" local y el diálogo proyectivo y heurístico que establece con el imaginario poético individual. Estos textos son: "Fundación de Valparaíso" de Miseria del hombre (1948) de Gonzalo Rojas; "El fugitivo" de Canto general (1950), las "Odas" en que se refiere a Valparaíso y otros poemas incluidos en La barcarola y Plenos poderes de Pablo Neruda y, finalmente, "Oceanía de Valparaíso" de Estilo de masas (1965) de Pablo de Rokha. Para estos poemas proponemos una lectura que se sustenta en el propósito de reconocerlos en el marco de lo que Solar (6) considera "una historia aparte", al referirse a la literatura de Valparaíso en relación con la desarrollada en la metrópoli; expresión que, desde nuestro punto de vista, ${ }^{6}$ deja en evidencia que el proceso de incorporación a la modernidad de los diversos espacios (sub)nacionales se llevó a cabo no sin subrepticios y enconados pleitos por el poder simbólico legitimador, correlativo a la unificación totalizante y homogeneizadora, que asume sin mayores cuestionamientos las manifestaciones de una única identidad "nacional" cultural, deponiendo o posponiendo las distinciones locales; distinciones cuyo reconocimiento no significa desconocer la producción instaurada como nacional, pues lo local "a su vez se inscribe en una realidad estructural, cuya lógica de funcionamiento trasciende las pautas locales" (Di Pietro, 2001:23). En todo caso, sostenemos que el relevamiento de

\footnotetext{
${ }^{5}$ Vattimo (1992), señala que la concepción de la poesía como evento fundante de un mundo histórico tiene un énfasis romántico que abandona la referencia a contenidos sentimentales en la relación poesía/realidad, y que corresponde luego a una "orientación general de las poéticas del siglo $\mathrm{XX}$, y ante todo de las vanguardias históricas". No obstante, reconoce que Heidegger, en su comentario el verso de Hölderlin "Lo que dura, lo fundan los poetas", al teorizar sobre el carácter fundante de la poesía "tiene el mérito de haber explicitado hasta el final las bases ontológicas de sus revoluciones, mostrando qué concepción del ser es preciso «adoptar» si se quiere verdaderamente salir de la mentalidad representativa de la metafísica".

${ }^{6}$ Solar no ofrece mayor explicación para su afirmación, limitándose a señalar que "[C]ada uno tiene la suya. Dejémoslo así. Es lo que justifica estas “Anotaciones para una Historia Aparte” (2001:6).
} 


\section{Adolfo de Nordenflycht}

las literaturas locales en su diferencialidad requiere determinar las modalidades de presencia del imaginario "geocultural" (Kusch, 2000) en la producción de escritores ligados a espacios locales que permita postular una historia efectiva, la que al decir de Foucault "no busca reconstruir el centro único del que provenimos, esa primera patria donde los metafísicos nos prometen que volveremos; intenta hacer aparecer todas las discontinuidades que nos atraviesan" (1988:67-68). De manera análoga, creemos que las entidades culturales locales llegan a ser las discontinuidades de la centralidad nacional homogeneizante, cuyas historias se articulan en dispositivos discontinuos, constelaciones, de comunidades que como señala Anderson deben distinguirse "por el estilo con el que son imaginadas" (1993:24). Estilo que, para el caso de las determinaciones territoriales regionales o locales, proviene de las prácticas del imaginario espacial (De Certeau, 2000:103-115), que las instaura y constituye. Los textos que revisaremos tienen distinta procedencia; fueron escritos en distintos momentos, desde diferentes estéticas y por poetas que la crítica nacional ha determinado como pertenecientes a distintas promociones. No obstante, tienen en común discurrir la experiencia del espacio local de Valparaíso a partir de la que se orientan para postular, a través de alguna figura que concentra la "fuerza problemática", aquello que en cada caso se manifiesta como fundamento de las aperturas del presente histórico en que se re-configura la dinámica identidad local de Valparaíso.

\section{ROJAS: EL MONSTRUO DE VALPARAÍSO}

"Fundación de Valparaíso" de Rojas es el poema final de Miseria del hombre (1948) y figura como una sección aparte de las cuatro anteriores. Lidia Dapaz, que lee el libro como un viaje de búsqueda, considera que en este poema, Valparaíso es "el signo exterior de una visión y evolución interior, la restauración a un estado paradisíaco, de paz y de cosmos de lo que empezó en un estado de caos" (1995:CXX) desde la primera sección. Entenderlo como llegada al paraíso, justificaría que el poema esté separado del resto en la organización del libro que correspondería al peregrinaje en su búsqueda. Al margen de ello, parece relevante recoger la idea de fundación como restauración del sujeto que se arroga el acto fundacional "a cuatrocientos años de haber sido pisada su playa por el godo" (127), como dice Rojas. Pisada su playa sí, pero no fundada como ciudad conforme a las normas del Derecho monárquico que instauraban la ciudad junto con su denominación, con el acto nombrar que era privativo del discurso del poder de la Corona. Por el contrario, el hablante del poema apela a otro poder que deviene del ámbito de los elementos: "Yo fundo esta ciudad [...] en nombre del viento" (127), dice. Se trata entonces de fundar lo existente sólo como realización de un fin natural (lugar de arribo) y otorgarle la calidad de acontecimiento de la historia, volviéndolo infinito e inagotable (ciudad y puerto), esto es dándole fundamento ("Yo fundo esta ciudad en fundamento inconmovible", reitera) que es lo que hace posible lo dado, en tanto lo condiciona, 
localiza y limita. Fundar, entonces, supone pretender con validez, lo cual exige un derecho que no es el del poder, sino el fundamento, que en el ámbito de la imaginación de la materia para el hablante del poema es la más sutil —el dinamismo del aire-, pues en el Valparaíso existente "Todo es parte del viento", afirma: cementerios, hombres, mujeres, tablas, cemento, mar, fuego, calles, mundo. El "anemos" fundador, no es ajeno a una larga tradición que emparienta verbo creador con soplo divino; en tanto que el aire para los mortales es lo que el éter para el mundo supralunar y un medio transmisor de todas las manifestaciones de la energía. Analogía en la que encuentra basamento la asociación entre palabra fundante y epifanía de lo sagrado. No obstante, el poema de Rojas introduce una variante que determina una diferente comprensión al señalar que ese viento, en nombre del que se funda y en el que se concentra reiterativamente todo lo existente como Valparaíso, "sale de las rocas", "sale de las cosas infladas por el viento", esto es, de lo terrestre, de la mínima materia que es la arena. "Todo es arena invulnerable. Todo era ilusión. No hubo sobre esta orilla del planeta nadie antes que el viento" (129) "Entonces tomo posesión del aire y de las rocas temporales" (129).

De manera que el movimiento fundante no apunta hacia lo abierto, hacia lo más alto, a escuchar el resonar del cielo, como observa Heidegger (1983), en su lectura de Hölderlin, reconociendo que el ser del poeta es el cántico que desde la tierra llama al cielo y a su vez la tierra es la novia a la que llega la canción del cielo. En Rojas, en cambio, lo fundante se orienta hacia un rumor del abismo, del volcán que puede oírse bajo la arena. De modo que el devenir a que da fundamento ese viento de las rocas es una caída hacia "la noche encendida debajo de la arena", una "noche matemática", no sagrada; es decir, noche del cálculo y el límite, del ritmo que abre - como apunta Agamben (2005:163) en otro contexto- el espacio de la pertenencia del hombre al mundo. Lo divino, el Dios de los relámpagos, es sólo una visión lejana que aparece en su silla fantástica en el cielo (alusión obvia a la silla del gobernador que se ve desde Valparaíso) envejecida (una ilusión), una vez que se despeja la incógnita. La caída a la arena primaria, a la boca del abismo —al ser bahía desnuda - es el "ritornello" (en el sentido que le reconocen a este término Deleuze y Guattari), ${ }^{7}$ sobre el que se construye la parte final del poema y el fundamento de su territorialidad. La ciudad, para ser fundada necesita de la palabra. "para fundarte necesito tenerte. Tu fundamento real es mi palabra" (130), dice el poeta no sin irónica ambigüedad (real es realidad y realeza) ¿Pero, bajo qué figura se funda, al margen de los dioses huidos, al margen de lo sagrado que es la presencia de una ausencia, de una alteridad indemne, al decir de Derrida (1997) ${ }^{8} \mathrm{El}$ poema dice: "Aguárdame sedienta para fundarte. Ahora caeré sobre ti como un

\footnotetext{
${ }^{7}$ Deleuze, Gilles y Felix Guattari, “A menudo, se ha resaltado el papel del ritornello: es territorial, es un agenciamiento territorial" (1994:319).

8 Rebok (en línea) sintetiza su aproximación hermenéutica a lo sagrado en las lecturas heideggerianas de Hölderlin haciendo referencia a la idea de Derrida que aquí se alude. Al estudio de Rebok debemos el habernos conducido a revisar esta propuesta derrideana.
} 


\section{Adolfo de Nordenflycht}

monstruo supremo más fuerte que el diluvio" (130). Si el diluvio es la disposición punible del Omnipotente, que destruye totalmente las arquitecturas humanas, la apropiación del monstruo es superior. Y, si el nosotros - como señalamosdepende de un territorio, Deleuze (1990) nos alerta que en mayor medida depende del agenciamiento del mismo, vale decir de la propiedad que se hace efectiva por la palabra en el doble movimiento de fundación de lo propio y de expropiación de lo impropio. La relación monstruo y viento ya ha sido prevista en un poema de la primera parte de Miseria del hombre (1948), que se titula sugestivamente "La poesía es mi lengua", en el que se afirma: "porque gusto mostrarme como un monstruo / para que el hombre entienda cuando soplan mis vientos" (16). Si se considera que la ciudad, la sociedad, se define por lo que excluye, se entiende que toda ciudad tiene su monstruo (dragón, esfinge, etc.), ese otro que habita más allá de sus límites, que representa la anormalidad requerida por la normalidad, "la negatividad necesaria para el advenimiento de la positividad plena"; fuera de límites, el monstruo es lo polimorfo por excelencia, "el símbolo de la totalización de las posibilidades naturales" (Durand, 1981:298). En buenas cuentas, la imagen del monstruo es mucho más vasta, refleja la tierra de nadie más allá de las fronteras de la sociedad, un territorio para el cual no tenemos un vocabulario ni una geografía; no es la carencia de una forma propia, es la propia naturaleza de suyo incognoscible que se muestra y se advierte; que se da presencia a sí misma en el momento que cae inconmensurable sobre la ciudad infundada y, por ello, en estado de miseria; al tiempo que la palabra poética se da fundamento en la paradojal afirmación de la implacable, feroz, tarea infinita de nombrar y nombrarse: "Te morderá mi boca / por los siglos terrestres" (130). En definitiva, la historia -en este caso los siglos desde el pie del godo - puede acontecer como historia sólo en cuanto es relación con la nada. La boca es, así, el espacio vacío ya no productor de palabras sino que se abre en la mordedura como un abismo que nos muestra, en la base a la continuidad de la experiencia, la nada sin la cual no hay fundación.

\section{NERUDA: SOLEDAD Y SILENCIO DEL PUERTO LOCO}

En numerosas ocasiones, Neruda tematizó los espacios urbanos de Valparaíso, al que en "Soy poeta de utilidad pública" (O.C.V) calificó como "conjunto — no diré ciudad ni diré puerto- el conjunto extraño de vidas humanas, abigarrado y magnífico, más impresionante de nuestro territorio" 309. Ni ciudad, ni puerto, lugar donde cabían el sueño y la ilusión, en cuyos cerros "se mezclan la miseria, la alegría y el trabajo como conjunciones conmovedoras" (310). El mismo año que se publica La Miseria del Hombre, Neruda escribe "El fugitivo", extenso poema en que - en las partes $\mathrm{V}$ y VI- alude a su permanencia clandestina en Valparaíso, poema que luego fue incorporado como la sección X de Canto General (1959), en tanto que en las secciones anteriores figuran las primeras menciones de Valparaíso que encontramos en su poesía. En "Obreros marítimos" (2005:258) alude a Valparaíso como un puerto miserable de obreros como pequeños dioses 
pobres, semidesnudos, malnutridos, y en "Mares de Chile" lo metaforiza como "ola de luz sola y nocturna, ventana al océano" (1999:660). Esta alusión a la miseria y a la soledad va a ser reiterativa en posteriores referencias a Valparaíso. En "El Fugitivo", se condensa la mirada del poeta cruzada por la de la ciudad ${ }^{9}$ (miré el limpio mantel, la jarra de agua / pura como esas vidas... Miré: la mesa estaba puesta. Fui a la ventana: Valparaíso abría sus mil párpados. [...]Junto a esa ventana de Valparaíso pasé días y noches (706) [...] En mi día solitario el mar / se alejaba: miraba entonces / la llama vital de los cerros / cada casa colgando, el / latido de Valparaíso: los altos cerros desbordantes / de vidas) (707). Pero se trata de una vida miserable, pobre desvencijada, desesperada, circunscrita por una niebla salobre que se extiende sobre las cosas: "todo eso - confiesa el hablante- envolvía mi cuerpo / como un nuevo traje terrestre, / y habité la bruma de arriba / el alto pueblo de los pobres" (708). Si los cerros son la miseria del presente, el mar y sus navegaciones remiten a un pasado decimonónico de orgullo y opulencia.

En la conocida "Oda a Valparaíso"(O.C. II) las contraposiciones se dan entre el mar y la tierra ("el beso / del ancho mar colérico / [...] / golpeándose en tu piedra / no pudo / derribarte" (245)..." y la tierra, / furiosa, / levantó su oleaje" 244), mar y tierra que se incorporan "al ámbito visual de la conciencia colectiva de los hombres, [y] transforman también los espacios de su existencia histórica", como señala Schmitt "y surgen entonces nuevas proporciones de la actividad histórico política" (2007:49.) En la "Oda a Valparaíso" se proclama que "en tu pecho austral están tatuadas la lucha, la esperanza, la solidaridad, la alegría como anclas que resisten las olas de la tierra" (245). De la tierra, pues como reafirma en la "Oda al espacio marino" "Yo no soy mar, soy hombre" (O.C. II:318), y el hombre es habitante de la tierra. En efecto, la imagen que sustenta al hombre del puerto es la de alguien que "Ha colgado / como araña / en las piedras, en / el erial marino, / su mansión miserable, / el hombre / de las tierras desdentadas" (316). Así, para Neruda, más que el mar y las faenas del puerto, lo propio de Valparaíso son los cerros. Dice: "el hombrecito / de la costa elevó las estructuras / y regresó a los cerros" (316), a esa tierra en movimiento, en terremoto, (¿Las olas de la tierra?) que es el espacio y la materia original. La tierra ha dejado que su energía traspase todo el espacio de Valparaíso, que los reinos oceánicos y telúricos se entrelacen en una confusión genésica. Un cuerpo molecular, gigante, rizomático, sin estratificaciones, desterritorializado por excelencia, como califica Deleuze a la tierra, añadiendo que se trata de un cuerpo "atravesado por materias inestables no formadas, flujos en todos los sentidos, intensidades libres o singularidades nómadas, partículas locas o transitorias" (Deleuze, 1990:47).

\footnotetext{
${ }^{9}$ Durand afirma: "Toda mirada es intercambio de miradas... digamos que toda mirada es cruzamiento de la del locutor y de la del o los destinatarios. Y el 'lugar común' en donde se constituyen esas miradas cuando se cruzan, el núcleo mejor compartido de la compresión, es el mito" (2003:154).
} 
No podemos extendernos en este aspecto; pero allí está la clave del Valparaíso como disparate, como puerto loco. El calificativo es decidor. Gabrielle Nouzeilles, al referirse a lo que considera los nuevos monstruos urbanos sostiene que la psiquiatría, "al estigmatizar al sujeto diferente como loco o neurótico, la representación figurada capturaba y controlaba la fuerza perturbadora de esa presencia otra, separando de ese modo al Yo racional, nacional pero vulnerable, del grupo de los desequilibrados" (1997:46). Si Valparaíso es "puerto loco", lo es en la medida, que se separa del sujeto nacional y se instaura como fuerza perturbadora, que se sostiene en una geografía atrabiliaria, una tierra hirsuta que corresponde al Valparaíso que se desarrolla, como se indica en "Al mismo puerto", poema incluido en Plenos Poderes (O.C. Vol. II)

Y bajo la espesura

de todo el mar cuando se desarrolla

[...] más allá, en el pecho

Del poeta,

Valparaíso cava

Y busca y halla

Y abre y deja

Una red emboscada en la firmeza” (1129).

En La barcarola, Neruda imagina una "Conversación marítima" (2004:101103) en las calles de Valparaíso con Rubén Darío, que es visto como "una sombra en las grietas del puerto, en el humo marino" (101). Si Gonzalo Rojas, en Fundación de Valparaíso, había dejado una seña, un guiño, al nicaragüense, ${ }^{10}$ Neruda se referirá directamente a Darío como "compañero" y como "mi padre poeta" (102) con el que se encuentra imaginariamente en el puerto. Así en el presente de la "Conversación marítima", entre los malecones, las bodegas abandonadas, los depósitos de mercaderías, los almacenes inmensos y vacíos, los arsenales con olor a invierno, en un Valparaíso en donde sólo llegan del sur (a causa del canal de Panamá) "los grandes navíos cargados de niebla mortuoria", se produce el encuentro con el que denomina "mi padre poeta" que surge como un fantasma que centraliza el acontecimiento apenas perceptible de la vibración de campana, de la música envuelta en sombra; un acontecimiento mínimo, casi sin referente o sólo autorreferente "algo vi o escuché

\footnotetext{
${ }^{10}$ En efecto, el hablante de Fundación de Valparaíso al asomarse al balcón que presumiblemente corresponde a la casa de cerro Alegre (calle San Enrique) donde efectivamente vivió Rojas a fines de la década de 1940, dice: "Yo salgo a mi balcón y ya no veo a nadie / No veo casas, ni mujeres rubias / Han desaparecido los jardines / Todo es arena invulnerable" (129). Sin duda que alude a la joven niña rubia en su jardín de casa de cuentos que llama la atención del "lírico incorregible" en su paseo de búsqueda de imágenes por el cerro Alegre en la sección "Álbum Porteño" del $A z u l$ de Darío (1888:83-84). Neruda (2005) parece aludir al mismo texto de Darío, rescatando la mirada del poeta incorregible desde el cerro sobre los sombreros de paño y de copa de la burguesía mercantil, para oponerlos al ligero e inadecuado sombrero del nicaragüense en "Conversación marítima" ("la lluvia de junio amenaza tu suave sombrero", 102).
} 
porque el hombre me miró sin mirarme ni oírme" , una experiencia — como señala Vattimo- "que se mueve sólo en las superficies, o añorando el original y considerándose decaída y alienada, o disfrutando la libertad que de tal modo le es reconocida en una suerte de delirio del simulacro" (1992:66). De Darío, el padre poeta, afirma Neruda (2005) tras el acontecimiento "Yo creo que allí constelado quedó, atravesado por rayos de luz inaudita", para terminar afirmando, Y no he visto silencio en el mundo como el de aquel hombre dormido, / dormido y andando y cantando en silencio por las calles de Valparaíso (102-103).

En la base de toda fundamentación, también de aquella operada por los poetas que "fundan lo que permanece", hay un abismo de des-fundamentación. El lenguaje fundante del poeta funda verdaderamente en cuanto está en relación con aquello que es otro que él, el silencio. Silencio que no es sólo el horizonte sonoro que la palabra necesita para resonar, para constituirse en su consistencia: es también el abismo sin fondo en que la palabra, pronunciada, se pierde. El silencio funciona en relación con el lenguaje como la muerte en relación con la existencia. Si el fundamento que Neruda propone para el espacio local de Valparaíso supone una re-territorialización de la tierra, un ganar una porción de tierra que deviene sostén de las cosas, igualmente el silencio y la soledad del puerto determina al hombre en relación con el territorio creado: las fisuras, corredores, saltos, planicies afectan la corteza íntima del grupo. Es el precio, quizá, que cobra la tierra por su división o la parcial ofrenda que ésta concede al atrevido fragmentador de la tierra-mar indistinta y loca, en plan, puerto, cerros. Es el precio que paga el incontenible flujo poético escasamente contenido en poema, soneto, oda, y en definitiva y paradójicamente, silencio.

\section{DE ROKHA: LA IMAGEN OCEÁNICA}

Estilo de masas (1965) se incluye en el marco de la "gran épica social de América" que había teorizado y venido practicando De Rokha desde los años 30 y en la cual el poeta se entendía como en una especie de adalid heroico que muestra - en metáforas - la realidad social. Como se sabe, al menos desde Arenga del arte (1949), De Rokha sostiene una visión materialista-dialéctica de los procesos artísticos — cuestión fundamental en su estética - en tanto que el poeta no puede ser ajeno a su entorno social y debe sumergirse en la realidad del tiempo que le toca vivir e interactuar con ella. Para argumentar su propuesta poética, De Rokha toma como base el desarrollo de la leyenda, que siendo expresión poética intuitiva de los pueblos, deviene interpretación artística de la realidad; de modo que la leyenda reemplazaría a la interpretación científica de la realidad, a la que el pueblo no tiene acceso, pues la clase explotadora se la ha escamoteado. En definitiva, la épica social construida por el poeta, es la manera de que el pueblo supere la enajenación, sublimando la realidad. Sostiene De Rokha "De la leyenda emerge la epopeya antigua y yo construyo la épica social americana, como mítico social del realismo insurgente y combatiente de los inmensos pueblos americanos" (1949:78). Los poemas, en tanto formas 


\section{Adolfo de Nordenflycht}

logradas, tienen que ser sociales y épicos y deben hablar de la historia trágica de las multitudes del continente. De esta manera, el artista es también un luchador social; un héroe y un creador de formas para las mayorías.

El poema sobre Valparaíso se estructura como una antítesis entre la exaltación de los orígenes y la conciencia de la decadencia transitoria del presente, desplazándose confusamente entre la apoteosis y la angustia

Te pareces inmensamente a tu retrato de espanto innumerable, copiado en los testamentos oceánicos, o acaso a la parición del mundo

eternamente sucedida

eternamente renovada (237).

Angustia y desazón que este puerto provoca en sus habitantes, ahora marginado respecto de los centros de modernidad y en el que la realidad se vuelve problemática, desintegrada e inestable, por lo tanto, un fenómeno difícil de asimilar y de representar, que sólo el sujeto poético heroico puede asumir, siendo el núcleo que estructura el marco general. Un sujeto heroico que se autoconfirma como el soporte de la pluralidad innumerable que dilata el texto; expandiéndose, asociándose, diluyéndose en los nuevos y antiguos conductores de pueblos, pero también en las multitudes, en el proletariado, en la humanidad

¡Oh Valparaíso!, cuando los años gusanos

[...] se coman las cosas, arañándolas y escarbándolas con las mandíbulas despedazadas tú y yo saliendo del espectro natural de las generaciones nos iremos desarrollando creciendo, es decir, viviendo y muriendo simultáneamente, sirviendo de espanto al ser humano, a la humanidad futura (249).

El poeta héroe sostiene y sucumbe a su propio laberinto de historias colectivas y contradicciones, de epopeyas y tragedias recomenzadas una y otra vez, "del mismo modo y manera como el poema es lenguaje de imágenes, es decir, de catástrofe" (244). La catástrofe sobreviene en el habitar manteniéndose en el cuerpo abigarrado que despliegan las imágenes de "Oceanía de Valparaíso", como "las casas colgadas sobre el abismo, como racimos de relojerías atroces, [que] le pertenecen trágicamente y épicamente al sistema planetario del cuotidiano del calendario sideral de Valparaíso" (245), en un impulso desmesurado que asume fragmentos de lugares simultáneos, jirones de memoria en el arrebato de una escritura desengañada. Valparaíso en la perspectiva de De Rokha es una visión de islas, una metafísica angustiosa del fragmento, de un continente de islas, una Oceanía que el poema va zurciendo de metáfora en metáfora y en el que la geografia de la ciudad es análoga con el propio poema enarbolando los fragmentos de su deseo heroico y su vértigo, como una escritura archipiélago, la única y posible escritura real. En efecto, y como lo consigna el prólogo póstumo de Genio del pueblo (1960), citando a Proust "sólo las metáforas sumergen el espíritu en lo real" (127); a lo que De Rokha se adelanta 
afirmando: "Definámonos en metáforas. Las raíces de Chile penetran la Oceanía" (126). En esta experiencia discontinua y fracturada del espacio del que habla el poema, Valparaíso es visto como el retazo de un naufragio interminable en los mares de la historia "Valparaíso, tú, Valparaíso con el terrible don huracanado de lo indescriptible, con el terrible sol tronchado, despedazado, rajado en abismos de lo sublime, en la mochila, como un gran poeta" (265); de modo tal que el objeto del canto, lo otro del yo, se vuelve el gran poeta, dándose fundamento abisal y sublime en lo despedazado, en lo tronchado. La estética contradictoria de este puerto del mundo, como lo señala De Rokha, termina por ser correlativa de su poética última; una poética en que el texto es catastrófico y donde la metáfora, la traslación, es un llevar hacia abajo como única solución a la tragedia del lenguaje —el lenguaje de la razón usurpada por la prosa capitalista - a la separación ilimitada de la palabra y la cosa, del sujeto y el objeto, de lo uno y lo múltiple. La Oceanía fundante de Valparaíso lo es también del propio poetizar y del lenguaje desde la propuesta de la épica social americana que se distinguiría - a nuestro juicio - en tanto se corresponde con la capacidad legitimatoria de una memoria histórica inserta en las urdimbres de significación que conciernan a territorialidades sociales vinculadas con un yonosotros objetivado que pugna dialécticamente por establecer un espacio social propio desde las relaciones de identificación / diferenciación que se dan al interior de las naciones-estado.

\section{CONCLUSIONES}

Considerando los textos que hemos analizado, podemos señalar que con ellos se configura una "constelación"11 de poéticas fundantes de Valparaíso, que se incorpora a la eventual "historia aparte" de la literatura porteña, postulada como reconocimiento de discontinuidades, que son (re)articuladas a partir de redundancias. En el caso que consideramos, tales redundancias se sustancian en la presencia determinante de ciertas imágenes en los textos de cada poeta, también en la pretensión fundante que comparten entre ellos y en el sentido mismo de la fundación, que en cierto modo también es redundancia, pues "fundar es reclamarse de un fundamento, plantear una cuestión como ya fundada" (Deleuze, 2007. En línea).

Por otra parte, hemos examinado de qué modo la ficción artística juega un rol fundamental en el redescubrimiento y en el reconocimiento de las revelaciones de experiencias históricas, tanto en sus relaciones con la imaginación individual (las poéticas o metapoéticas de autor) como en sus relaciones con el imaginario colectivo que utiliza y que contribuye a enriquecer y a modificar; esto es, las relaciones que mantiene con lo social y con la historia local, en que la ficción del espacio realiza la

\footnotetext{
${ }^{11}$ La metáfora de la constelación ha sido empleada en distintas disciplinas y por diversos autores (LeviStrauss, Adorno, Maffesoli, Durand, etc.). Aquí, la retomamos como una herramienta que permite articular discontinuidades, dado que teniendo un carácter abierto (la constelación se configura desde la mirada del observador) resulta eficiente como figura de base, plausible aunque inestable, para reconocer los flujos, yuxtaposiciones y entre-cruzamientos de los discursos literarios en que se sustancia el imaginario local.
} 
instalación del paisaje de un devenir colectivo que corresponde al hábitat interpretado, determinante para la comunidad en tanto se particulariza como formante de la identidad local. Ahora bien, como las identidades no son fijas, sustanciales, sino por el contrario, relacionales, contingentes, hay que reconocer que el hábitat interviene dialécticamente en la formación identitaria local que, aunque acallada, desdeñada e inhibida, resulta más auténtica y en definitiva vigorosa, en tanto se desarrolla en los tiempos largos de la historia. Lo que se requiere entonces para que haya identidades locales es lo que Bourdieu (1988) ha denominado "poder simbólico", poder fundante de consagración (no en vano en el mundo antiguo, el numen constituía la sacralidad del lugar colectivo) o revelación de las cosas que ya existen.

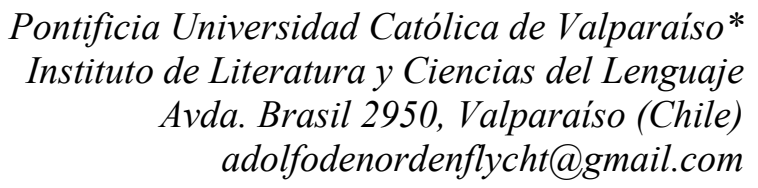

BIBLIOGRAFÍA

Adorno, Theodor. Dialéctica negativa. Madrid: Taurus, 1986.

Anderson, Benedict.Comunidades imaginadas. Reflexiones sobre el origen y la difusión del nacionalismo. México: F.C.E., 1993.

Agamben, Giorgio. El hombre sin contenido. Barcelona: Áltera, 2005.

Bourdieu, Pierre. "Espacio social y poder simbólico", en Cosas dichas. Buenos Aires: Gedisa, 1988.

Dapaz, Lidia. "La Miseria del hombre como viaje de descubrimiento". En Rojas, Gonzalo. Miseria del hombre. Valparaíso: Puntángeles / Universidad de Playa Ancha, 1995:CXV-CLXVII.

Darío, Rubén. Azul. Valparaíso: Imprenta y litografía Excelsior, 1888.

De Certeau, Michel. La invención de lo cotidiano. México D.F. Universidad Iberoamericana, 2000.

De Rokha, Pablo. "Oceanía de Valparaíso", en Estilo de masas. Santiago de Chile: Prensa Latinoamericana, 1965.

------- Genio del Pueblo. Segunda edición extraordinaria, limitada, numerada, rectificada y aumentada por el autor. Santiago de Chile: Multitud, 1960.

------ Arenga sobre el arte. Santiago de Chile: Klong, 1949.

Deleuze, Gilles. “¿Qué es fundar? Curso hypokhâgne, Licée Louis Le Grand 19561957. Notas manuscritas tomadas por Pierre Lefebvre", en Les Cours de Gilles Deleuze. 2007. Web. Consultado: Noviembre 9 del 2010.

$<\mathrm{http} / /$ www.webdeleuze.com/php/texte.php?cle=229\&groupe=Conf\%E9rences \&langue $=3>$

Deleuze, Gilles; Guattari, Felix. Mil mesetas. Capitalismo y esquizofrenia. Valencia: Pre-Textos, 1994.

Derrida, Jacques. “Fe y saber. Las dos fuentes de la 'religión' en los límites de la mera razón”, en Derrida, Jacques y Gianni Vattimo (Eds). La religión (Seminario de Capri, 1994). Buenos Aires: Ediciones de la Flor, 1997. 
Di Pietro Paolo, Luis José. "Hacia un desarrollo integrador y equitativo: una introducción al desarrollo local”. 2001. Consultado: Noviembre 6 del 2010. $<$ http://www.trabajoydiversidad.com.ar/Articulo\%20Di\%20Pietro\%20Desarrollo\%2 0Local\%5B2\%5D.pdf>.

Durand, Gilbert. Mitos y Sociedades: Introducción a la mitología. Buenos Aires: Biblos, 2003.

------ Las Estructuras antropológicas de lo imaginario. Madrid: Taurus, 1981.

------ Figures mythiques et visages de l'oeuvre: de la mythocritique à la mythanalyse, Paris: Berg International, 1979.

Foucault, Michel. Nietzsche, la genealogía, la historia. Valencia: Pre-Textos, 1988.

Heidegger, Martin. "El Cielo y la Tierra de Hölderlin", en Interpretaciones de la poesía de Hölderlin. Barcelona: Ariel, 1983:163-192. Consultado: Octubre 29 del 2010. $<\mathrm{http}: / /$ www.heideggeriana.com.ar/textos/cielo_y_tierra.htm>

Kusch, Rodolfo. Geocultura del hombre americano. Rosario: Fundación Ross, 2000.

Le Dantec, Francisco. Crónicas del viejo Valparaíso. Valparaíso: Ediciones Universitarias de Valparaíso de la Universidad Católica de Valparaíso (1ª edición: 1984), 2003.

Neruda, Pablo. Canto General. Santiago de Chile: Pehuén, 2005.

------ La barcarola. Edición y notas de Hernán Loyola. Prólogo de María Gabriela Mizraje. Buenos Aires: Debolsillo, 2004.

------ "Soy un poeta de utilidad pública", en Obras completas de Pablo Neruda. Vol. V. Nerudiana dispersa 1922-1973. Edición de Hernán Loyola. Barcelona: Galaxia Gutenberg Círculo de Lectores, 2002.

------ Plenos Poderes, en Obras completas de Pablo Neruda. Vol. II. Edición de Hernán Loyola. Barcelona: Galaxia Gutenberg Círculo de Lectores, 1999.

"El fugitivo", Canto General, en Obras completas de Pablo Neruda. Vol. I. Edición de Hernán Loyola. Barcelona: Galaxia Gutenberg Círculo de Lectores, 1999.

Nouzeilles, Gabrielle. "Ficciones paranoicas de fin de siglo: naturalismo argentino y policía médica”. MLN 112, 1997.

Rojas, Gonzalo. "Fundación de Valparaíso", en Miseria del hombre. Valparaíso: Puntángeles/Universidad de Playa Ancha, 1995.

Rebok, María Gabriela. "Hólderlin y Heidegger: una poética de lo sagrado". Consultado: Noviembre 6 del 2010.

$<\mathrm{http} / / /$ proyectohermeneutica.org/pdf/paneles/mg_rebok.pdf.

Sáez Godoy, Leopoldo. Valparaíso. Lugares, nombres y personajes. Siglo XVI-XXI. Valparaíso. Coedición Universidad de Playa y Editorial Bachillerato en Ciencias y Humanidades Universidad de Santiago de Chile, 2001.

Schmitt, Carl. Tierra y mar. Madrid: Editorial Trotta, 2007.

Solar, Claudio. Historia de la literatura de Valparaíso. Valparaíso: Gran Fraternidad de escritores y de artistas de Valparaíso, 2001.

Vattimo, Gianni. Más allá del sujeto. Nietzsche, Heidegger y la hermenéutica. Barcelona: Paidós. 1992. Consultado: Noviembre 6 del 2010.

$<$ http://www.heideggeriana.com.ar/comentarios/poesia_como_ocaso.htm> 